\title{
Analisis Faktor-Faktor yang Memengaruhi Penerapan Standar Akuntansi Pemerintah pada Kantor Wilayah Kementerian Hukum dan HAM Sumatera Selatan
}

\author{
Eriza Khosakiyah, Vhika Meiriasari \& Andini Utari Putri \\ Universitas Indo Global Mandiri \\ Email: eriza.khosakiyah@yahoo.com
}

\begin{abstract}
This study aims to investigate the influence of the quality of human resources, government accounting system, and political process on the application of government accounting standards at the Ministry of Law and Human Rights of South Sumatra. The population was all 152 employees at the Ministry of Law and Human Rights. Data were collected through questionnaires to 40 respondents and analysed using multiple linear regression on SPSS V25. The results prove that partially the quality of human resources and the government accounting system affects the application of government accounting standards. Conversely, the political process has no effect on the application of government accounting standards. Simultaneously, the quality of human resources, government accounting systems, and political processes have an effect on the application of government accounting standards.
\end{abstract}

Keywords: human resource quality, government accounting system, political process, application of government accounting standards.

\section{Pendahuluan}

Dalam rangka menciptakan tatakelola pemerintahan yang baik (good governance) pemerintah Indonesia terus melakukan berbagai usaha untuk meningkatkan transparansi dan akuntabilitas pengelolaan keuangan negara, salah satunya adalah dengan melakukan pengembangan kebijakan akuntansi pemerintah berupa standar akuntansi pemerintah (SAP) yang bertujuan memberikan pedoman pokok dalam penyusunan dan penyajian laporan keuangan baik di pemerintah pusat maupun di pemerintah daerah (Hasibuan, 2015). Standar Akuntansi pemerintah merupakan salah satu aspek penting yang diperlukan untuk meningkatkan kualitas tata kelola keuangan negara dan pelaporan keuangan pemerintah. Perubahan pengelolaan keuangan Negara masih terus dilakukan secara berkelanjutan. Hal ini dimaksudkan agar amanat yang tertuang dalam pasal 3 ayat (1) undang-undang No. 17 tahun 2003 tentang keuangan negara, yang mengharuskan keuangan negara dikelola secara tertib, taat pada perundang-undangan, efisien, efektif, ekonomis, transparan dan bertanggung jawab dengan memperhatikan rasa keadilan dan ketaatan dapat semangkin diwujudkan. Pemerintah telah menetapkan peraturan pemerintah Republik Indonesia No 24 tahun 2005 tentang standar akuntansi pemerintah yang telah diganti dengan penetapan peraturan pemerintah Republik Indonesia No 71 tahun 2010 tentang SAP berbasis akrual SAP berbasis akrual.

Dengan demikian, SAP merupakan prinsip-prinsip akuntansi yang diterapkan berdasarkan perwujudan undang-undang No. 17 tahun 2003 adalah menetapkan standar akuntansi pemerintah berbasis akrual yang ditetapkan dalam bentuk peraturan pemerintah PP No. 71 Tahun 2010 sebagai pengganti dari peraturan pemerintah PP No. 24 Tahun 2005 tentang standar akuntansi pemerintah berbasis kas. Sementara itu untuk pengakuan 
dan pengukuran pendapatan berbasis akrual menurut pasal 36 ayat 1 Undang-Undang No 17 Tahun 2003 harus dilaksanakan selambat-lambatnya dalam 5 (lima) tahun. Perubahan standar akuntansi pemerintah menuju berbasis akrual akan membawa dampak kepada pengelolaan keuangan Negara. Untuk melaksanakan dan Menerapkan standar akuntansi yang sudah ditentukan, pemerintah harus memiliki sumber daya manusia yang handal sehingga mampu menyusun laporan keuangan pemerintahannya berdasarkan Standar Akuntansi Pemerintah (SAP). Menurut Muindro (2010), Akuntansi Pemerintahan adalah akuntansi yang berkaitan sengan anggaran Negara. Akuntansi Pemerintahan dilaksanakan baik oleh unit-unit pemerintah (eksekutif) dan juga lembaga legislatif dan yudikatif sepanjang membebani anggaran Negara. Akuntansi Pemerintah mencatat dan melaporkan transaksi kegiatan anggaran negara berupa pendapatan (revenues) dan belanja (expenditures), pembiayaan (financing). Di samping itu, dengan adanya otonomi daerah, pengelolaan keuangan sepenuhnya berada ditangan pemerintah daerah. Untuk itu keharusan dan tuntutan transparansi kinerja keuangan daerah memberikan gambaran pentingnya Standar Akuntansi Pemerintah untuk diberlakukan sehingga akan ada keseragaman penilaian terhadap kinerja pemerintah daerah. Upaya untuk mewujudkan hal tersebut kesungguhan dan komitmen para aparat dalam pemerintahan yang bersangkutan sebagai pelaku dan penyusun laporan keuangan pemerintah bagi yang memerlukan atau pihak yang berkepentingan.

Kemampuan SDM merupakan hal yang penting dalam membuat laporan keuangan yang berguna sebagai informasi bagi lingkungan pemerintah daerah tersebut, maupun sebagai informasi yang penting dalam penelitian yang akan dilakukan oleh pemerintah pusat melalui BPK. Penerapan sistem akuntansi pemerintah ini perlu dilakukan, terutama karna konsep akuntansi akrual di lingkungan pemerintah masih sangat baru, dan juga amanat undang-undang agar pemerintah segera menggunakan standar akuntansi pemerintah berbasis akrual, Penerapan sistem akuntansi pemerintah berbasis akrual merupakan proses yang berkesinambungan dan terpadu. Dampak yang dihasilkan dari penerapan sistem akuntansi pemerintah ini tidak dapat dilihat dalam waktu yang singkat. Pemahaman tentang faktor-faktor yang mempengaruhi keberhasilan atau kegagalan dalam pengenalan sistem akuntansi yang baru, khususnya pada konteks pemeritah adalah penting. Keberhasilan dan kegagalan penerapan akuntansi pemerintah tidak lepas dari peran satuan kerja dan pengaruh dari faktor-faktor Kualitas sumber daya manusia, sistem akuntansi pemerintah, dan proses politik.

Kualitas sumber daya manusia menjadi faktor penting dalam menghasilkan laporan keuangan yang berkualitas. Jika kompetensi sumber daya manusia dilaksanakan dengan baik, maka kualitas laporan keuangan daerah akan meningkat, sehingga laporan keuangan yang baik dapat memenuhi karakteristik kualitatif laporan keuangan. Dengan demikian kualitas sumber daya manusia ditunjukkan agar penyelenggaraan tugas dan fungsi organisasi dalam rangka menghasilkan laporan keuangan daerah yang berkualitas dapat diterapkan. Sistem akuntansi pemerintah dapat diartikan sebagi rangkaian sistematik, dari prosedur, penyelenggaraan, peralatan dan elemen lain untuk mewujudkan fungsi akuntansi sejak analisis transaksi sampai dengan pelaporan keuangan di lingkungan pemerintah daerah. Sistem akuntansi pemerintah daerah dalam hal pengelolaan keuangan daerah secara baik, harus dilakukan dengan mewujudkan tujuan pemerintahan yang bersih (clean government), dimana pengelolaan keuangan daerah yang baik adalah kemampuan mengontrol kebijakan keuangan daerah secara ekonomis, efisien, efektif, 
transparan dan akuntanbel. pada prinsipnya sistem akuntansi pemerintah daerah telah menetapkan standar akuntansi pemerintah berbasis akrual diharapkan dapat mewujudkan transparansi dan akuntabilitas pengelolaan laporan keuangan pemerintahan baik pusat maupun daerah dan menjadi sangat penting karena fungsinya dalam menentukan kualitas informasi pada laporan keuangan. Proses politik memiliki peranan dalam negara demokratis yang berada dalam lembaga perwakilan dapat mempengaruhi kebijakan pemerintah dalam pembuatan standar akuntansi atau yang biasa disebut standar akuntansi pemerintah berbasis akrual sehingga political willingness sangatlah mempunyai dampak positif dan peranan yang penting dalam penyusunan dan pelaporan keuangan pemerintahan sehingga menghasilkan Pengelolahan keuangan pemerintah lebih akuntabel, transparan, dan dapat melihat pengelolahan keuangan mulai dari pengelolahan perencanaan, monitoring, dan evaluasi (Putra, 2015). Pada saat penetapan standar akuntansi pemerintah dianggap mempengaruhi perilaku ekonomi dengan demikian akuntansi dapat mempengaruhi perilaku manusia dan proses yang disebut dengan proses politik

Penelitian ini menarik untuk dilakukan, karena diketahui bahwa terdapat fenomena laporan keuangan pemerintah daerah yang belum diselenggarakan sesuai dengan standar akuntansi pemerintah berbaris akrual sesuai dengan peraturan pemerintah No 71 tahun 2010 yang mana pada Kementerian hukum dan HAM sumatera selatan masih belum menerapkan secara penuh standar akuntansi pemerintah berbasis akrual dengan kata lain masih belum menggunakan basis akrual untuk keseluruhan proses akuntansinya atau masih menggunakan basis kas menuju akrual. terbukti dari laporan keuangan yang dihasilkan yang telah peneliti diuraikan diatas terdiri dari laporan realisasi anggaran, neraca, laporan operasional dan laporan perubahan ekuitas bahwa hanya laporan keuangan neraca yang menggunakan basis akrual selebihnya masih menggunakan basis kas. Hal tersebut dikarenakan berbagai macam kendala yang dihadapi dalam penerapan SAP baru, adanya kelebihan dan kekurangan, serta peluang dan tantangan dalam penerapan basis ini sehingga perlu dibuat kajian terhadap berbagai macam perubahan SAP, serta perlu adanya pengkajian terhadap berbagai macam perspektif dari penerapan SAP yang telah diundangkan tersebut sehingga diharapkan mampu menjadi pandangan bagi para satuan kerja pemerintahan untuk menerapkan SAP dengan basis akrual secara penuh (full accrual). Hal yang paling baku muncul adalah terkait sumber daya manusia pemerintah daerah. Sumber daya manusia yang kurang memadai menjadi masalah klasik dalam pengelolaan keuangan negara. Hal ini meliputi SDM yang kurang kompeten dan cenderung resisten terhadap perubahan.

Herlina (2013) meneliti mengenai analisis faktor-faktor yang mempengaruhi kesiapan pemerintah daerah dalam imolementasi PP No 71 Tahun 2010 studi empiris Kabupaten Nias Selatan. Kesimpulan yang didapat di dalam penelitian ini adalah bahwa dari keseluruhan item yang dianalisis dihasilkan tiga faktor yang mempengaruhi kesiapan Pemerintah Daerah dalam implementasi sistem akuntansi berbasis akrual yaitu informasi, prilaku, dan keterampilan. Dari tiga faktor yang memengaruhi tersebut merupakan ekstraksi dari enam belas item pernyataan yang merupakan bagian dari lima variabel yang memengaruhi kesiapan Pemerintah Daerah dalam implementasi sistem akuntansi pemerintahan bebasis akrual yaitu komunikasi, kompetensi sumber daya manusia, struktur birokras, komitmen pimpin, dan resistensi terhadap perubahan. 
Pemahaman tentang faktor-faktor yang memengaruhi keberhasilan atau kegagalan dalam pengenalan sistem akuntansi yang baru, khususnya pada konteks pemerintahan adalah penting. Keberhasilan atau kegagalan penerapan akuntansi berbasis akrual pada pemerintah tidak lepas dari peran satuan kerja dan pengaruh dari faktor-faktor yang ada pada satuan kerja tersebut, mulai dari faktor sumber daya manusia seperti tingkat pendidikan staf, pelatihan yang diberikan, dan latar belakang, maupun faktor situasional lainnya seperti pengalaman satuan kerja dalam menjalankan basis kas menuju akrual dan ukuran satuan kerja tersebut. Adapun tujuan penelitian ini adalah sebagai berikut: (1) Untuk menganalisis kualitas sumber daya manusia, sistem akuntansi Pemerintah, Proses politik berpengaruh terhadap penerapan Standar Akuntansi Pemerintah Pada Kantor Wilayah Kementerian Hukum dan HAM Sumatera Selatan; (2) Untuk menganalisis kualitas sumber daya manusia berpengaruh terhadap penerapan Standar Akuntansi Pemerintah Pada Kantor Wilayah Kementerian Hukum dan HAM Sumatera Selatan; (3) Untuk menganalisis Sitem akuntansi Pemerintahan berpengaruh terhadap Penerapan Standar Akuntansi Pemerintah Pada Kantor Wilayah Kementerian Hukum dan HAM Sumatera Selatan; (4) Untuk Menganalisis Proses Politik berpengaruh terhadap Penerapan Standar Akuntansi Pemerintah pada Kantor Wilayah Kementerian Hukum dan HAM Sumatera Selatan.

\section{Tinjauan Literatur}

Dalam teori entitas yang dikemukakan oleh Paton (Suwardjono, 2015), dinyatakan bahwa organisasi dianggap sebagai suatu kesatuan atau badan usaha ekonomik yang berdiri sendiri, bertindak atas nama sendiri, dan kedudukannya terpisah dari pemilik atau pihak lain yang menanamkan dana dalam organisasi dan kesatuan ekonomik tersebut menjadi pusat perhatian atau sudut pandang akuntansi. Dari perspektif ini, akuntansi berkepentingan dengan pelaporan keuangan kesatuan usaha, bukan pemilik. Kesatuan usaha merupakan pusat pertanggung jawaban dan laporan keuangan merupakan medium pertanggung jawabannya

Dalam mekanisme keuangan negara di Indonesia, teori ataupun konsep entitas tersebut telah diaplikasikan dalam Undang-undang Nomor 1 Tahun 2004 tentang Perbendaharaan Negara. Undang-undang Nomor 1 Tahun 2004 menyatakan tiap-tiap kementerian negara/lembaga merupakan entitas pelaporan yang tidak hanya wajib menyelenggarakan akuntansi, tetapi juga wajib menyampaikan laporan pertanggungjawaban berupa laporan keuangan. Berdasarkan Pernyataan Standar Akuntansi Pemerintahan, berikut adalah pengertian dari entitas pelaporan dan entitas akuntansi: (1) Entitas pelaporan adalah unit pemerintahan yang terdiri dari satu atau lebih entitas akuntansi atau entitas pelaporan yang menurut ketentuan peraturan perundang-undangan wajib menyampaikan laporan pertanggungjawaban berupa laporan keuangan; (2) Entitas Akuntansi adalah unit pemerintahan pengguna anggaran / pengguna barang dan oleh karenanya wajib menyelenggarakan akuntansi dan menyusun laporan keuangan untuk digabungkan pada entitas pelaporan.Pemerintah daerah sebagai entitas pelaporan wajib menyampaikan laporan keuangannya. Laporan keuangan diharapkan dapat memberikan informasi keuangan kepada berbagai kelompok kepentingan yang ingin mengetahui entitas secara lebih dalam, di mana adanya perbedaan karakteristik antar entitas yang akan memberikan perbedaan nilai dalam laporan keuangan masing-masing entitas. Laporan keuangan kemudian digunakan untuk memonitor dan membandingkan kinerja keuangan antar 
entitas yang sejenis (Mardiasmo, 2015).

Dari uraian diatas dapat di simpulkan bahwa hubungan teori entitas terhadap penerapan standar akuntansi pemerintah yaitu Pemerintah Pusat, Pemerintah daerah, dan satuan organisasi di lingkungan Pemerintahan Pusat atau daerah, jika menurut peraturan perundang-undangan satuan organisasi yang dimaksud wajib menyajikan laporan keuangan. Sesuai dengan peraturan yang berlaku saat ini yaitu Peraturan Pemerintah Nomor 71 tahun 2010 lampiran 2, maka Pemerintahan diwajibkan melaksanakan akuntansi pemerintah dalam menyusun laporan keuangan untuk tujuan umum disusun dan disajikan dengan basis akrual /cash accrual. Pernyataan Standar ini berlaku untuk entitas pelaporan dalam menyusun laporan keuangan suatu entitas pemerintah pusat, pemerintah daerah, dan laporan keuangan konsolidasian.

Berdasarkan PP No 71 Tahun 2010, Standar Akuntansi Pemerintah diartikan sebagai prinsip-prinsip akuntansi yang diterapkan dalam penyusunan dan penyajikan laporan keuangan pemerintah dalam bentuk pernyataan Standar Akuntansi Pemerintah (SAP), serta disusun dengan mengacu pada kerangka konseptual akuntansi pemerintah. Standar akuntansi pemerintah merupakan acuan dalam menyusun laporan keuangan. Sehingga standar akuntansi keuangan merupakan faktor penting yang dapat menigkatkan kualitas laporan keuangan yang dihasilkan. Sumber daya manusia merupakan pengakuan tentangnya tenaga kerja organisasi sebagai sumber daya manusia yang sangat penting dalam memberi kontribusi bagi tujuan-tujuan organisasi, dan menggunakan beberapa fungsi dan kegiatan untuk memastikan bahwa sumber daya manusia tersebut digunakan secara efektif dan adil bagi kepentingan individu, organisasi dan masyarakat dalam meningkatkan kinerja Schuler Et Al, dalam (Sutrisno, 2019). Menurut Nawawi (2012) sumber daya manusia sebagai salah satu unsur dalam organisasi dapat diartikan sebagai manusia yang bekerja dalam suatu organisasi. Sumber daya manusia dapat disebut juga sebagai personil, tenaga kerja, pekerja, karyawan, potensi manusiawi sebagai penggerak organisasi dalam mewujudkan eksistensinya. Atau potensi nyata secara fisik dan non fisik dalam mewujudkan eksistensi organisasi.

Sistem akuntansi pemerintah adalah Sistem akuntansi pemerintah dapat diartikan sebagi rangkaian sistematik, dari prosedur, penyelenggaraan, peralatan dan elemen lain untuk mewujudkan fungsi akuntansi sejak analisis transaksi sampai dengan pelaporan keuangan di lingkungan pemerintah daerah (permendagri No.64 tahun 2013). Proses politik dalam pembuatan regulasi atau standar akuntansi dapat dideskripsikan sebagai usaha salah satu atau banyak pihak untuk melakukan self-interest dalam penyusunan standar akuntansi atau upaya memaksimalkan transfer kekayaan.

Kusuma (2013) melakukan penelitian terkait analisis faktor-faktor yang mempengaruhi penerapan akuntansi akrual pada Pemerintah, kota Semarang dengan hasil penelitian Tingkat akuntansi akrual pada pemerintah masih sangat rendah. Secara khusus tingkat penerapan akuntansi akrual dipengaruhi secara signifikan dari tingkat pendidikan staf, kualitas teknologi informasi, dukungan konsultan, pengalaman, latar belakang, pendidikan pimpinan dan ukuran satuan kerja terhadap tingkat penerapan akuntansi akrual.

Berdasarkan Kajian Teori yang telah djabarkan maka hipotesis dari penelitian ini adalah :

$\mathrm{H}_{1} \quad$ Kualitas Sumber daya manusia, Sistem akuntansi Pemerintahan dan Proses politik 
berpengaruh terhadap penerapan Standar Akuntansi Pemerintah Pada Kantor Wilayah Kementerian Hukum dan HAM Sumatera Selatan.

$\mathrm{H}_{2} \quad$ Kualitas Sumber daya manusia berpengaruh terhdap penerapan Standar Akuntansi Pemerintah Pada Kantor Wilayah Kementerian Hukum dan HAM Sumatera Selatan.

$\mathrm{H}_{3} \quad$ Sistem akuntansi Pemerintahan berpengaruh terhadap Penerapan Standar Akuntansi Pada Kantor Wilayah Kementerian Hukum dan HAM Sumatera Selatan.

$\mathrm{H}_{4} \quad$ Proses Politik berpengaruh terhadap Penerapan Standat Akuntansi Pemerintah Pada Kantor Wilayah Kementerian Hukum dan HAM Sumatera Selatan.

\section{Metode Penelitian}

Disini penulis akan menganalisi faktor-faktor yang berkaitan dengan Penerapan Standar Akuntansi Pemerintah pada Kantor Wilayah Kementerian Hukum dan HAM Sumatera Selatan. Teknik analisis yang digunakan untuk mengetahui faktor-faktor yang memengaruhi tingkat penerapan standar akuntansi pemerintah pada Kantor Wilayah Kementerian Hukum dan HAM Sumatera Selatan adalah dengan metode Analisis Regresi Linear Berganda dengan bantuan Software SPSS Versi 25, metode ini menggambarkan suatu hubungan dimana satu atau lebih variabel (variabel Independen) mempengaruhi variabel lainnya (variable dependen). Uji regresi linier berganda digunakan analisis untuk mengukur besarnya pengaruh antara dua atau lebih variable independen terhadap satu variabel dependen dan memprediksi variabel dipenden dengan menggunakan variabel independen (Fauzi, Dencik \& Asiati, 2019). Dalam regresi linier berganda terdapat asumsi klasik yang harus terpenuhi yaitu resdual berdistribusi normal, tak ada multikolinearitas, dan tak ada heteroskedastisitas.

$\mathrm{Y}=\mathrm{a}+\mathrm{b}_{1} \mathrm{X}_{1}+\mathrm{b}_{2} \mathrm{X}_{2}+\mathrm{b}_{3} \mathrm{X}_{3}+\mathrm{e}$

Keterangan :

$\mathrm{Y} \quad=$ Penerapan Standar Akuntansi Pemerintah

$\mathrm{X} 1=$ Kualitas Sumber Daya Manusia

$\mathrm{X} 2=$ Sistem Akuntansi Pemerintah

$\mathrm{X} 3=$ Proses Politik

A $\quad=$ Konstanta

bx $\quad=$ Slope regresi atau koedisien regresi dari $\mathrm{X}_{\mathrm{x}}$

$\mathrm{E} \quad=$ Kesalahan residual

\section{Hasil dan Pembahasan}

\subsection{Uji Simultan (Uji F)}

Uji Statistik F pada dasarnya menunjukkan apakah semua variabel independen atau bebas yang dimasukkan dalam model regresi mempunyai pengaruh secara bersama-sama terhadap variabel dependen untuk mengambil keputusan hipotesis diterima atau ditolak dengan membandingkan tingkat signifikan sebesar 0,05. Jika Probability F lebih besar dari 0,05 maka model regresi tidak dapat digunakan atau memprediksi variabel dependen dengan kata lain variabel independen secara bersama-sama tidak berpengaru hterhadap 
variabel dependen (Ghozali, 2011). Untuk itu, dilakukan pengujian hipotesis simultan sebagai berikut:

Tabel 1. Hasil Uji Simultan (Uji F)

\begin{tabular}{|l|r|r|r|r|r|}
\hline \multicolumn{6}{|c|}{ ANOVA a $^{|c|}$} \\
\hline Model & $\begin{array}{l}\text { Sum of } \\
\text { Squares }\end{array}$ & df & $\begin{array}{r}\text { Mean } \\
\text { Square }\end{array}$ & F & Sig. \\
\hline Regression & 64,238 & 3 & 21,413 & $\begin{array}{r}13,3 \\
98\end{array}$ &, $000^{\mathrm{b}}$ \\
\hline Residual & 57,537 & 36 & 1,598 & & \\
\hline Total & 121,775 & 39 & & & \\
\hline $\begin{array}{l}\text { a. Dependent Variable: Penerapan_Standar_Akuntansi } \\
\text { b. Predictors: (Constant), Proses_Politik, Kualitas_SDM, } \\
\text { Sistem_Akuntansi_Pemerintah }\end{array}$
\end{tabular}

Dari hasil uji simultan (uji F) di atas dapat diketahui bbahwa secara bersama-sama variabel independen memiliki pengaruh yang signifikan terhadap variabel dependen. Hal ini dapat dibuktikan dari nilai probabilitas 0,000 yang memiliki nilai lebih kecil dari 0,05 yang berarti model penelitian ini dapat diterima. Hasil uji tersebut sejalan dengan hipotesis penelitian yang menyatakan bahwa semua variabel memberi pengaruh terhadap penerapan standar akuntansi pemerintah.

\subsection{Uji Parsial (Uji t)}

Uji nilai $\mathrm{t}$ digunakan untuk mengetahuitingkat pengaruh setiap satu variabel bebas terhadap variabel terikat Sebuah variabel bebas dapat dikatakan berpengaruh pada variabel terikat apabila nilai signifikan yang dihasilkan dalam pengujian pada tiap-tiap variabel bebas lebih kecil dari alpha $(<0,05)$. Hasil pengujian hipotesis secara persial untuk penelitian ini sebagai berikut:

Tabel 2. Hasil Uji Parsial (Uji t)

\begin{tabular}{|l|r|r|r|}
\hline Model & $\begin{array}{c}\text { Standardized } \\
\text { Coefficients }\end{array}$ & \multirow{2}{*}{$\mathrm{t}$} & \multirow{2}{*}{ Sig. } \\
\cline { 2 - 5 } & \multicolumn{1}{|c|}{ Beta } & & \\
\hline & &, 822 &, 416 \\
\hline 1 &, 292 & 2,442 &, 020 \\
\hline $\begin{array}{l}\text { (Constant) } \\
\text { Kualitas_SDM }\end{array}$ &, 607 & 5,056 &, 000 \\
\hline $\begin{array}{l}\text { Sistem_Akuntansi_ } \\
\text { Pemerintah }\end{array}$ &, 151 & 1,290 &, 205 \\
\hline
\end{tabular}


Berdasarkan hasil pada tabel di atas, menjelaskan masing-masing variabel secara persial dan hasil output pengolahan data melalui spss dan penjelasan untuk tiap-tiap variabel adalah sebagai berikut:

\subsection{Pengaruh Kualitas Sumber Daya Manusia, Sistem akuntansi Pemerintah dan Proses Politik terhadap penerapan Standar Akuntansi Pemerintah}

Dari hasil uji hipotesis yang telah dilakukan menyatakan hipotesis pertama $\left(\mathrm{H}_{1}\right)$ diterima, sehingga menunjukan bahwa kualitas sumber daya manusia, sistem akuntansi pemerintah dan proses politik berpengaruh secara bersama-sama terhadap penerapan standar akuntansi pemerintah. Hal tersebut menunjukan bahwa semakin tinggi nilai kualitas SDM, sistem akuntansi pemerintah, dan proses politik maka berhubungan positif dan dapat menjadi faktor untuk meningkatkan nilai penerapan standar akuntansi pemerintah dalam rangka menciptakan pemeritahan yang baik dengan adanya otonomi daerah, pengelolaan keuangan sepenuhnya berada ditangan pemerintah daerah untuk itu keharusan dan tuntutan transparansi kinerja keuangan memberikan gambaran pentingnya penerapan standar akuntansi pemerintah untuk diberlakukan sehingga akan nada keseragaman penilaian terhadap kinerja pemerintah. Upaya untuk mewujudkan hal tersebut kesungguhan kualitas sumber daya manusia, Sistem Akuntansi Pemerintah dan proses politik merupakan pilar penyangga sekaligus penggerak roda organisasi dalam mewujudkan visi dan misi serta tujuan dari pemerintah dengan dikeluarkannya peraturan pemerintah Republik Indonesia Nomor 71 tahun 2010 tentang standar akuntansi pemerintah berbasis akrual.

Hasil penelitian ini sejalan dengan penelitian terdahulu yang dilakukan oleh Nufus (2014) yang menyimpulkan bahwa Sistem Akuntansi Pemerintahan, proses politik dan kualitas sumber daya manusia secara simultan berpengaruh terhadap penerapan Standar akuntansi pemeritah.Jika dibandingkan dengan hasil penelitian dan penelitian terdahulu dapat diketahui bahwa pada hasil penelitian ini memperoleh hipotesis alternatif (Ha) yang diterima, sedangkan Hipotesis Nol (Ho) ditolak. Hal ini memebuktikan bahwahi potesis yang berbunyi ada pengaruh Standar Akuntansi Pemerintah, Sumber Daya Manusia Dan Kualitas Teknologi Informasi Terhadap Penerapan Akuntansi Akrua terbukti kebenarannya.

\subsection{Pengaruh Kualitas Sumber Daya Manusia terhadap Penerapan Standar Akuntansi Pemerintah}

Dari hasil uji parsial atau uji t dalam penelitian ini hipotesis kedua (H2) menunjukkan bahwa Kualitas sumber daya manusia berpengaruh positif dan signifikan terhadap Penerapan Standar akuntansi pemerintah. Dapat dilihat pada tabel 2 nilai thitung sebesar 2,442 dengan tingkat signifikansi 0,020 yang artinya lebih kecil dari nilai $\alpha=0,05$ yang artinya menolak Ho. Dari hasil pengujian tersebut dapat disimpulkan bahwa hipotesis kedua $(\mathrm{H} 2)$ dalam penelitian ini yang mengharapkan bahwa kualitas sumber daya manusia secara signifikan berpengaruh terhadap Penerapan standar akuntansi pemerintah dapat diterima. Artinya Kualitas Sumber daya manusia menjadi faktor penting dalam mengimplementasikan Penerapan standar akuntansi pemerintah untuk menghasilkan laporan keuangan yang berkualitas sesuai dengan standar yang berlaku. Jika kompetensi sumber daya manusia dilaksanakan dengan baik, maka kualitas laporan keuangan daerah akan meningkat, sehingga laporan keuangan yang baik dapat memenuhi karakteristik kualitatif laporan keuangan. 
Hasil penelitian ini sejalan dengan hasil penelitian Nasition (2016), Ariyanto (2015), Nufus (2014) dan Ardiansyah ( 2013) yang menyimpulkan bahwa Kualitas sumber daya manusia berpengaruh terhadap penerapan standar akuntansi pemerintah. Namun hasil penelitian ini tidak sejalan dengan hasil penelitian Herlina (2013) yang menyatakan bahwa Kualitas sumber daya manusia tidak berpengaruh terhadap penerapan standar akuntansi pemerintah. Hubungannya dengan Teori Entitas Yaitu dalam mekanisme keuangan negara di Indonesia telah diaplikasikan dalam undang-undang Nomor 1 Tahun 2004 yang menyatakan tiap-tiap kementrian negara/lembaga merupakan entitas pelaporan yang tidak hanya wajib menyelenggarakan akuntansi, tetapi juga wajib menyampaikan laporan pertanggungjawaban berupa laporan keuangan.

\subsection{Pengaruh Sistem Akuntansi Pemerintah terhadap Penerapan Standar Akuntansi Pemerintah}

Dari hasil uji parsial atau uji t dalam penelitian ini hipotesis ketiga (H3) menunjukkan bahwa Sistem akuntansi Pemerintah berpengaruh positif dan signifikan terhadap Penerapan Standar akuntansi pemerintah. Dapat dilihat pada tabel 2 nilai thitung sebesar 5,056 dengan tingkat signifikansi 0,000. Hal ini berarti lebih kecil dari nilai $\alpha=0,05$ maka dari hasil uji di atas dinyatakan $\mathrm{HRR}_{0} \mathrm{RR}$ ditolak. Dari hasil pengujian tersebut dapat disimpulkan bahwa hipotesis kedua (H3) dalam penelitian ini yang mengharapkan sistem akuntansi pemerintah secara signifikan berpengaruh terhadap Penerapan standar akuntansi pemerintah dapat diterima. Hal ini menunjukan sistem akuntansi pemerintah di era keterbukaan informasi yang saat ini berlaku, tentu informasi atas laporan keungan juga menjadi penting bagi pemerintah dalam hal ini sistem membuat korporasi-korporasi memperbaiki kualitas dari laporan keuangan dan menerapkan basis akrual dalam pelaporannya mewacanakan transparasi yaitu dengan memberikan informasi kepada rakyat atas kegiatan finansial pemerintah yang diimplementasikan dengan terbitnya peraturan pemerintah No 71 Tahun 2010.

Hubungannya teori entitas yaitu sistem akuntansi pemerintah yang mendukung pelaksanaan standar akuntansi pemerintah karna suatu unit pemerintah pusat maupun daerah dituntut harus melaporkan laporan pertanggung jawaban berupa laporan keuangan menurut ketentuan perundang-undangan yang telah diatur dan perkembangan entitas ekonomi yang ada, sehingga pembentukan standar akuntansi bukanlah suatu proses yang berjalan serta-merta, namun sangat memperhatikan aspek konsekuensi ekonomi yang diakibatkan. Pemerintah telah menerapkan SAP Berbasis Akrual, yaitu SAP yang mengakui beban, aset, utang dan ekuitas dalam pelaporan finansial berbasis akrual, serta mengakui pendapatan, belanja, dan pembiayaan dalam pelaporan pelaksanaan anggaran berdasarkan basis yang ditetapkan dalam APBN/APBD. SAP Berbasis Akrual tersebut dinyatakan dalam bentuk PSAP dan dilengkapi dengan Kerangka Konseptual Akuntansi Pemerintahan. yaitu pelayanan publik serta nomor rekening perkiraan yang digunakan.

\subsection{Pengaruh Proses Politik terhadap Penerapan Standar Akuntansi Pemerintah}

Dari hasil uji parsial atau uji t dalam penelitian ini hipotesis empat (H4) menunjukkan bahwa proses politik bahwa nilai $t_{\text {hitung }}$ sebesar 1,290 dengan tingkat signifikansi 0,205 yang artinya lebih besar dari nilai $\alpha=0,05$ maka dari hasil uji di atas dinyatakan $H_{R}{ }_{0} R R$ diterima yang artinya secara parsial proses politik tidak berpengaruh secara signifikan terhadap penerapan standar pemerintah. Dari hasil pengujian tersebut dapat disimpulkan bahwa hipotesis keempat (H4) dalam penelitian ini bahwa proses politik tidak 
berpengaruh secara signifikan terhadap Penerapan standar akuntansi pemerintah.

Koefisien regresi variabel proses politik menunjukan bahwa hubungan antara proses politik terhadap Penerapan Standar akuntansi pemerintah adalah tidak searah. Hasil uji koefisien regresi bahwa proses politik tidak berpengaruh terhadap penerapan standar akuntansi pemerintah sehingga hipotesis ditolak. Dalam penelitian ini proses politik menunjukan hasil positif dan tidak signifikan.Artinya proses politik tidak selalu berpengaruh dalam pembuatan regulasi atau standar akuntansi. Entitas akuntansi merupakan unit pada pemerintahan yang mengelola anggaran, kekayaan, dan kewajiban yang menyelenggarakan akuntansi dan menyajikan laporan keuangan atas dasar akuntansi yang diselenggarakan. Entitas pelaporan adalah unit pemerintahan yang terdiri dari satu atau lebih entitas akuntansi, yang menurut ketentuan peraturan perunndang undangan wajib menyampaikan laporan pertanggungjawaban, berupa laporan keuangan yang bertujuan umum yang terdiri dari pemerintah pusat dan pemerintah daerah.

\section{Kesimpulan}

Berdasarkan hasil pengolahan data yang telah dijabarkan pada bab sebelumnya, dengan demikian dapat ditarik kesimpulan sebagai berikut: (1) Kualitas sumber daya manusia, Sistem Akuntansi Pemerintah, dan proses politik secara signifikan berpengaruh terhadap Penerapan standar akuntansi pemerintah dengan nilai signifikan sebesar 0,000 lebih kecil dari 0,05 ; (2) Kualitas sumber daya manusia secara signifikan berpengaruh terhadap Penerapan standar akuntansi pemerintah, nilai signifikan yang dihasilkan sebesar 0,020 lebih kecil dari 0,05; (3) Sistem Akuntansi Pemerintah secara signifikan berpengaruh terhadap Penerapan standar akuntansi pemerintah, nilai signifikan sebesar 0,000 lebih kecil dari 0,05; (4) Proses politik secara signifikan tidak berpengaruh terhadap Penerapan standar akuntansi pemerintah, dengan nilai signifikan sebesar 0,205 lebih besar dari 0,05.

Untuk mengimplementasikan Regulasi pada PP No 71 Tabun 2010 disarankan lebih meningkatkan kompetensi sumber daya manusia agar dapat menghindari resiko dalam perda kebijakan akuntansi dengan cara melakukan pelatihan serta sosialisasi lebih mendalam dengan memberikan diklat mengenai standar akuntansi pemerintah berbasis akrual sehingga para pengguna dan pelaksana anggaran dalam proses pencatatan ataupun penatausahaan keuangan daerah dilaksanakan sesuai dengan standar yang dipakai saat ini, yaitu PP No 71 Tahun 2010.

\section{Referensi}

Aditia, D., Nasution, D., \& Sari, T. A. (2015). Analisis faktor-faktor yang mempengaruhi komitmen skpd sebagai variabel moderating pada Pemerintah Provinsi Sumatera Utara. 18(4), 175-185.

Ardiansyah. (2013). Faktor - faktor yang mempengaruhi kesiapan pp no 71 tahun 2010 tentang standar akuntansi pemerintah (Studi kasus pada Satuan Kerja di Wilayah Kerja KPPN Malang). Jurnal Akuntansi Universitas Brawijaya, 1, 18-29.

Arif, B. dkk. (2012). Akuntansi Pemerintahan (Edisi pert). Salemba empat.

Ariyanto, D. (2015). Faktor - faktor yang mempengaruhi penerapan standar akuntansi pemerintah berbasis akrual. Jurnal Akuntansi Universitas Udayana, 13, 14-3.

Bastian, I. (2016). Akuntansi sektor Publik: Suatu Pengantar. Erlangga. 
Brahim, P. (2013). Akuntansi Akrual dan Penerapannya di Sektor Publik. Telaah Pustaka.

Devi Safitri. (2017). Faktor - faktor yang mempengaruhi penerapan standar akuntansi pemerintahan berbasis akrual (Studi pada SKPD Pemerintah Kabupaten Bengkalis). Jurnal Akuntansi, 5(2), pp. 32T32TUUhttps://doi.org/10.1017/CBO9781107415324.004UU32T

Ekonomika, F., Kristen, U., Wacana, S., Ekonomika, F., Kristen, U., \& Wacana, S. (2014). Tingkat Pemahaman Penyusun Laporan Keuangan. 71, 1920-1938.

Fauzi, F., Dencik, A. B., \& Asiati, D. I. (2019). Metodologi Penelitian Untuk Manajemen dan AKuntansi. Jakarta: Salemba Empat.

Ghozali, I. (2013). Aplikasi Analisis Multivariate Dengan Program SPSS. Badan Penerbit Universitas Diponegoro.

Ghozali, I. (2013). Metode Penelitian. Bandung. Pustaka Setia.

Halim. (2013). Akuntansi Sektor Publik (Edisi 2). Salemba empat.

Herlina, H. (2013). Analisis faktor - faktor yang mempengaruhi kesiapan pemerintah daerah dalam implementasi Pp 71 Tahun 2010 (Studi empiris pada Kabupaten Nias Selatan. Jurnal Akuntansi Fakultas Ekonomi Universitas Negeri Padang.

Nufus, K. (2014). Faktor-faktor yang mempengaruhi penerapan standar akuntansi pemerintah pada pemerintah Kota Baubau. Jurnal Liquidity, 3.

Kristyono, J. (2013). Faktor yang mempengaruhi keberhasilan pelaksanaan keuangan daerah sesuai PP 71 Tahun 2010 (Studi pada Dinas Pendidikan Kota Semarang Tahun 2012/2013. Jurnal Akuntansi Fakultas Ekonomi Pandanaran Semarang, 1, pp. 46-57.

Kusuma. (2013). Analisis Faktor - Faktor yang Mempengaruhi Tingkat Penerapan Akuntansi Akrual Pada Pemerintah. Jurnal Akuntansi Fakultas Ekonomi Dan Bisnis Universitas Diponegoro, 3, pp. 525-538.

Lelono, Khoirul Maarif Joko. (2014). Tingkat Pemahaman Akuntansi Berbasis Akrual pada penyusun Laporan Keuangan Pemerintah Daerah (studi pada SKPD di lingkungan pemerintah Kota Salatiga). Salatiga.

Mariska, (2013). Pengaruh standar akuntansi pemerintahan dan good governance terhadap kualitas laporan keuangan pemerintah daerah. Jurnal Universitas Lampung.

Mediaswati, R. (2013). Standar akuntansi pemerintahan dalam mewujudkan akuntabilitas dan transparansi pengelolaan keuangan daerah. JKAP (Jurnal Kebijakan Dan Administrasi Publik), 17(1), pp. 29-45. 32T32Thttps://doi.org/10.22146/jkap.684732T

Nugraheni, P., \& Subaweh, I. (2008). Pengaruh penerapan standar akuntansi pemerintahan terhadap kualitas laporan keuangan. Jurnal Ilmiah Ekonomi Bisnis, 13(1), 48-58. 32T32Thttps://doi.org/10.35760/eb.2008.v13i1.32132T

Rahmayati, F. (2012). Faktor-Faktor yang mempengaruhi Kualitas Laporan Keuangan Kementrerian Negara/Lembaga (Studi pada Satuan Kerja di Wilayah Kerja KPPN Surabaya II). Skripsi. Malang: Universitas Brawijaya.

Riana, DS. (2014). Standar akuntansi pemerintahan dan sistem pengendalian intern sebagai anteseden kualitas laporan keuangan pemerintah daerah. Jurnal Penelitian 
Akuntansi, XI(1).

Safitri, D., Yusralaini, Y., \& Asri, F. (2015). Faktor-faktor yang mempengaruhi kesiapan penerapan standar akuntansi pemerintah berbasis akrual. Jurnal Online Mahasiswa Fakultas Ekonomi Universitas Riau, 2(1), pp. 14-32.

Sedermayati. (2013). Manajemen Sumber Daya Manusi, Reformasi Birokrasi Dan Manajemen Pegawai Negri Sipil. Bandung: Refika Aditama.

Simanjuntak, Binsar H. (2010). Penerapan Akuntansi Berbasis Akrual di Sektor Pemerintahan Indonesia. Jakarta: Disampaikan pada Kongres XI Ikatan Akuntansi Indonesia.

Sugiyono. (2013). Metode Penelitian Kuantitatif, Kualitatif, Dan R\&D (Cetakan Ke 22 ed.). Bandung: Alfabeta.

Sugiyono. (2018). Metode Penelitian Manajemen (Cetekan Ke-6 ed.). Bandung: Alfabeta.

Sujarweni, \& Wiratna. (2014). Metode Penelitian Manajemen. Yogyakarta: Pustaka Beru Press.

Susilawati, S., \& Riana, D. S. (2014). standar akuntansi pemerintahan dan sistem pengendalian intern sebagai anteseden kualitas laporan keuangan pemerintah daerah. STAR - Study \& Accounting Research, XI(1), 15-32.

Sulistiani, AT. (2004). Manajemen Sumber Daya Manusia. Yogyakarta: Graha Ilmu.

Suwardjono. (2015). Penerapan akuntansi sektor public terhadap laporan keuangan instansi pemerintah Kabupaten Banyumas. Fakultas Ekonomi dan Bisnis UMP.

Tarigan, Erwinton P.Antonius \& Nurtanzila, Lastria. (2013). Standar Akuntansi Pemerintahan Dalam Mewujudkan Akuntabilitas dan Trasparansi Pengelolaan Keuangan Daerah. Jurnal Kebijakan dan Adminstrasi Publik,.17(1), pp. 29-45.

Phambudi. (2019). Analisis Penerapan Standar Akuntansi Pemerintah Berdasarkan PP No 71 Tahun 2010 Terhadap Kinerja Keuangan Pada Satuan Kerja Polesta. Skripsi Fakultas Ekonomi Universitas Diponegoro.

\section{Copyrights}

Copyright for this article is retained by the author(s), with first publication rights granted to the journal.

This is an open-access article distributed under the terms and conditions of the Creative Commons Attribution license (http://creativecommons.org/licenses/by/4.0/) 